International Law Studies - Volume 81

International Law Challenges:

Homeland Security and Combating Terrorism

Thomas McK. Sparks and Glenn M. Sulmasy (Editors)

\title{
XVII
}

\section{The Legality of Operation Iraqi Freedom under International Law}

\author{
Michael N. Schmitt*
}

I

$\mathrm{n}$ the months preceding the attack on Iraq by the US-commanded "coalition of the willing," few issues captured greater international attention than the legality of the impending armed conflict. Even United Nations Secretary-General Kofi Annan entered the fray, intimating that an attack without the imprimatur of a Security Council mandate would violate the UN Charter. ${ }^{2}$ Once Operation Iraqi Freedom began on March 19, 2003, however, one might have expected the brouhaha to die down, particularly given the speed of victory, and the fact that the troubled occupation should have diverted attention from jus ad bellum reservations. ${ }^{3}$ Indeed, controversy regarding the legality of the two campaigns the United States and United Kingdom had recently conducted, Operations Allied Force and Enduring Freedom, ${ }^{4}$ faded quickly once hostilities ended.

Yet, as this article is being written in early 2004, the controversy over Iraqi Freedom rages on. The 2004 US presidential election campaign has contributed to the staying power of the issue. So too have the transatlantic and intra-European

\footnotetext{
* Professor of International Law, George C. Marshall European Center for Security Studies, Garmisch-Partenkirchen, Germany. The views expressed herein are those of the author in his personal capacity and do not necessarily represent those of any United States or German government agency. This article was published previously in volume 3, no. 2 of the Journal of Military Ethics (2004) and is reprinted with permission.
}

The opinions shared in this paper are those of the author and do not necessarily reflect the views and opinions of the U.S. Naval War College, the Dept. of the Navy, or Dept. of Defense. 


\section{The Legality of Operation Iraqi Freedom under International Law}

divides created, or at least exacerbated, by virulent opposition to the war on the part of some European States, especially France and Germany. The seeming inability of weapons inspectors to locate the alleged weapons of mass destruction (WMD) capabilities that President Bush pointed to so frequently as war clouds loomed, and the failure to find a smoking gun tying Iraq to $\mathrm{Al}$ Qaeda, have added fuel to the fire.

Given the panoply of justifications for the operation bandied about by governments, politicians, political commentators, legal experts, non-governmental organizations, and the public at large, Iraqi Freedom serves as a fascinating jus ad bellum case study. This article considers those most commonly posed-implicit Security Council authorization, self-defense against State support to terrorism, anticipatory (often mislabeled preemptive) self-defense against terrorism and weapons of mass destruction, breach of the 1991 cease-fire, humanitarian intervention, and regime change. States mounting the attack formally proffered only breach of the cease-fire that ended the first Gulf War as its legal basis. However, unofficial sources in policy and academic circles floated the others as independent grounds for the action, and the States involved cited each as a de facto, albeit not legal, factor legitimizing the attack.

\section{Implicit Security Council Authorization}

The most universally accepted basis for the use of force is authorization by the United Nations Security Council. Before granting it, the Council must determine, pursuant to Article 39 of the UN Charter, that a particular situation amounts to a threat to the peace, breach of the peace, or act of aggression. Once it does so, the Security Council must first attempt to resolve the matter by employing non-forceful measures, such as an embargo. ${ }^{5}$ If non-forceful actions prove unsuccessful, or if it believes that attempting them would be "inadequate," the Council may then, acting under Article 42, "take such action by air, sea, or land forces as it may deem necessary to maintain or restore international peace and security." Such actions are known as "Chapter VII enforcement operations," a reference to the Charter chapter in which the relevant articles appear.

This decision generally comes in the form of a Security Council resolution containing a mandate to use "all necessary means" to achieve a specified end. For instance, Resolution 678 of 1990 authorized "Member States cooperating with Kuwait" to use all necessary means to "uphold and implement Security Council Resolution 660 and all subsequent relevant resolutions and to restore international peace and security." 6 Resolution 660 had demanded the withdrawal of Iraqi forces from Kuwait following their August 1990 invasion. ${ }^{7}$ Mandates can be issued to 
individual States or an ad hoc coalition thereof, to a regional security organization such as NATO, or to a UN commanded and controlled force. ${ }^{8}$

As events unfolded in late 2002 and early 2003, the United States and United Kingdom actively sought a Security Council mandate for action against Iraq. However, the best they could achieve was Resolution 1441, which did not contain the desired "all necessary means" clause. ${ }^{9}$ Both countries abandoned subsequent efforts to secure a follow-on use of force resolution when France and Russia threatened to exercise their veto authority.

Resolution 1441, passed unanimously on November 8, condemned Iraq's failure to fully disclose information about its weapons of mass destruction and ballistic missile programs, ${ }^{10}$ cooperate with weapons inspectors, ${ }^{11}$ end ties to terrorism, ${ }^{12}$ cease repression of its population, ${ }^{13}$ facilitate humanitarian assistance by aid agencies, ${ }^{14}$ and cooperate in accounting for missing individuals and property from the first Gulf War. ${ }^{15}$ The resolution went on to find Iraq in "material breach" of these obligations under various resolutions, including Resolution 687, which, as conspicuously noted in 1441, set forth the terms of the 1991 cease-fire. After granting Iraq "a final opportunity" to comply with its disarmament obligations, imposing detailed requirements regarding the future weapons inspection regime, and demanding that Iraq "cooperate immediately, unconditionally, and actively" with inspectors from the International Atomic Energy Agency (IAEA) and United Nations Monitoring, Verification and Inspection Commission (UNMOVIC), the resolution ominously "recalled" "that the Council has repeatedly warned Iraq that it will face serious consequences as a result of its continued violations of its obligations."

With war drawing close, some argued that Resolution 1441, standing alone, implicitly authorized the impending attack. The resolution specifically noted that the Security Council was operating under Chapter VII of the UN Charter, which provides the basis for authorizing the use of force in response to a threat to the peace. Although it gave Iraq a final opportunity to meet its obligations, Chief UN Weapons Inspector Hans Blix briefed the Council on March 7, 2003 that Iraq had not cooperated "immediately," as required by Resolution $1441 .{ }^{16}$ Finally, the resolution warned of "serious consequences" if Iraq failed to meet the Council's conditions. Given prior sanctions on Iraq, the phrase could only have been a reference, so the argument goes, to forceful disarmament. Thus, when Iraq failed to cooperate immediately with the inspectors, the 1441 condition precedent for the use of force presented itself.

This line of reasoning is fundamentally flawed. First, the lack of the "all necessary means" clause evidences the Council's discord over whether armed force constituted the appropriate remedy for Iraq's failure to meet its obligations. Moreover, 


\section{The Legality of Operation Iraqi Freedom under International Law}

in 1990 the Security Council had likewise given Iraq a "final opportunity" to meet its obligations under prior resolutions, most significantly withdrawal from $\mathrm{Ku}-$ wait. ${ }^{17}$ But on that occasion it also authorized Member States that were cooperating with Kuwait to "use all necessary means" to uphold and implement the resolutions and "restore international peace and security in the area" if Iraq failed to comply with them by January 15,1991 . Thus, Iraqi non-compliance automatically triggered the use of force mandate. Resolution 1441 contained no such trigger.

In fact, only the non-inclusion of the "all necessary means" language made Resolution 1441's adoption possible. During the Security Council session that approved the resolution, France, Russia, and China insisted that they viewed 1441 as but the first step in a two-step process, and that only the Council could decide what to do in the event of Iraqi non-compliance. The French Ambassador was particularly pointed: "France welcomes the fact that all ambiguity on this point and all elements of automaticity have disappeared from the resolution." 18

Tellingly, US Ambassador Negroponte conceded as much in his own remarks.

As we have said on numerous occasions to Council members, this resolution contains no "hidden triggers" and no "automaticity" with respect to the use of force. If there is a further Iraqi breach, reported to the Council by UNMOVIC, the IAEA or a Member State, the matter will return to the Council for discussions as required in paragraph $12 .{ }^{19}$

Portentously, he went on to qualify his comments.

The resolution makes clear that any Iraqi failure to comply is unacceptable and that Iraq must be disarmed. And, one way or another, Iraq will be disarmed. If the Security Council fails to act decisively in the event of further Iraqi violations, this resolution does not constrain any Member State from acting to defend itself against the threat posed by Iraq or to enforce relevant United Nations resolutions and protect world peace and security. ${ }^{20}$

Consistent with this approach, the United States later returned to the Security Council to urge armed force, most famously on February 5, 2003 when Secretary of State Colin Powell briefed it on Iraq's failures and urged the Council to "not shrink from whatever is ahead." ${ }^{21}$ As noted, the Council did not act, a failure that led President Bush to proclaim: "The United Nations Security Council has not lived up to its responsibilities, so we will rise to ours." 22 Therefore, it should be apparent that when Coalition forces attacked days later, their legal basis for armed action was not Resolution 1441; nor would the resolution have provided a proper basis had they made such an assertion. 


\section{Self-Defense against State Support to Terrorism}

Beyond Security Council authorization to use force under Chapter VII, the only other explicit exception to Charter Article 2(4)'s broad prohibition on the use of force ${ }^{23}$ is self-defense pursuant to Article 51 . Article 51 provides that "[n] othing in the present Charter shall impair the inherent right of individual or collective selfdefense if an armed attack occurs against a Member of the United Nations, until the Security Council has taken measures necessary to maintain international peace and security." Thus, whereas a mere threat to the peace suffices to engage the Security Council's right to mandate forceful enforcement measures, an armed attack is the condition precedent for self-defense.

The terrorist attacks of September 11, 2001 crystallized the applicability of the law of self-defense to acts of terrorism. The following day the Security Council passed Resolution 1368 affirming the "inherent right of self-defense as recognized by the Charter of the United Nations." On September 28, it again cited the right to self-defense in Resolution 1373, which set forth a number of measures to combat terrorism. Subsequent resolutions reaffirmed 1368 and 1373, thus implicitly acknowledging that the situation implicated the right to self-defense. ${ }^{24}$

However, by March 19, 2003, Iraq had not conducted terrorist attacks against the United States, nor was there an immediate threat of it doing so. True, in 1993, Iraq had been involved in an assassination plot against former President George Bush, Sr., to which the United States responded with cruise missile strikes. But since then, no known terrorist attacks have been conducted by Iraqi agents. Therefore, any justification of Operation Iraqi Freedom related to ongoing terrorism must be based on Iraq's support of terrorists, such as Al Qaeda.

The law surrounding the use of force against State supporters of terrorism has experienced a sea change over the past two decades. Recall that Operation El Dorado Canyon, the 1986 package of US air strikes against Libya following a terrorist attack in Berlin that targeted US military personnel, generated nearly universal condemnation. With the exception of Israel and the United Kingdom, even close allies of the United States criticized the operation. ${ }^{25}$ The General Assembly passed a resolution condemning it as a violation of international law, ${ }^{26}$ and Secretary-General Javier Perez de Cueller stated that he "deplored" the "military action by one member state against another." 27

State support of guerilla forces surfaced in a judicial opinion rendered the same year. In Military and Paramilitary Activities, a case between the United States and Nicaragua, the International Court of Justice addressed the appropriateness of imputing an armed attack to a State because of its sponsorship of rebels such that military action against the State itself is appropriate in self-defense. ${ }^{28}$ The Court held 


\section{The Legality of Operation Iraqi Freedom under International Law}

that a State committed an armed attack by "the sending by or on behalf of a State of armed bands, groups, irregulars or mercenaries, which carry out acts of armed force against another State of such gravity as to amount to (inter alia) an actual armed attack conducted by regular forces, or its substantial involvement therein." ${ }^{29}$ The opinion went on to state that " $t$ ] his description, contained in Article 3, paragraph (g), of the Definition of Aggression annexed to General Assembly Resolution 3314 (XXIX), may be taken to reflect customary international law." 30 Reduced to basics, the requirement was that the group be acting on behalf of the State or that the State have been otherwise highly involved in the actual operation.

Yet, when the United States and United Kingdom directly attacked the Taliban, the de facto government of Afghanistan, because of its decision to "allow the parts of Afghanistan that it controls to be used by [Al Qaeda] as a base of operations," 31 the international community was very supportive. In addition to UK participation in the initial strikes, Georgia, Oman, Pakistan, the Philippines, Qatar, Saudi Arabia, Tajikistan, Turkey, and Uzbekistan provided airspace and facilities. China, Egypt, Russia, and the European Union publicly backed the operations, while even the Organization for the Islamic Conference limited itself to urging the United States to restrict its campaign to Afghanistan. ${ }^{32}$ Australia, Canada, the Czech Republic, Germany, Italy, Japan, The Netherlands, New Zealand, Turkey, and the United Kingdom offered ground troops. ${ }^{33}$ Paradoxically, this all occurred in spite of the fact that the Taliban were more dependent on Al Qaeda (for support in its conflict with the Northern Alliance) than vice versa, and therefore did not appear to fit the Military and Paramilitary Activities standard.

Particularly indicative of the shifting attitude towards the degree of State support that rises to the level of an armed attack is the fact that the justification for attacking the Taliban was contained in the required US notification to the Security Council that it was acting in self-defense. Therefore, the international community was clearly on notice that the United States characterized its action as one in selfdefense and it appears to have accepted the premise that, in appropriate circumstances, State supporters of terrorism risk a military response pursuant to that right.

That said, the precise level of State support that amounts to an armed attack remains uncertain. The horror of 9/11, particularly the number of casualties and the direct targeting of innocent civilians, clearly contributed to international acceptance of the US response. So too did the fact that the United Nations had repeatedly warned the Taliban to put an end to terrorist activities on its territory, ${ }^{34}$ as had the United States post-9/11..$^{35}$ The fact that the Taliban were internationally ostracized made striking them even more palatable. Nevertheless, the attack against the Taliban and the response thereto were certainly watershed events for the law 
surrounding lawful responses to State support of terrorism. Without any doubt, the degree of support necessary to constitute an armed attack has dropped precipitously.

And what of Iraq's complicity in terrorism? Failure of occupation forces to find a direct link between Saddam Hussein and Al Qaeda attacks (or any other terrorist forces actively conducting operations against the United States) is relevant, but not dispositive. International law judges actors by what they reasonably believed under the circumstances. ${ }^{36}$ Therefore, the question is not whether there were links between Iraq and terrorists, but rather would any links the United States rationally thought existed, even mistakenly, have justified an attack on Iraq in self-defense?

Defensive actions must also meet the legal criteria of necessity and proportionality in the face of an immediate threat. ${ }^{37}$ Necessity requires that there be no reasonable alternative to the use of force; proportionality limits the force used to that required to actually defeat the attack; and imminency requires the self-defense to occur only during the last window of opportunity to mount an effective defensive operation.

Secretary of State Powell provided the most comprehensive picture of what the United States believed regarding Iraqi complicity in his February 5, 2003 briefing to the Security Council. The Secretary made the case that "Iraq . . . harbours a deadly terrorist network headed by Adu Musab al-Zarqawi, an associate and collaborator of Osama bin Laden and his Al Qaeda lieutenants." ${ }^{38}$ According to Powell, Zarqawi set up a terrorist training camp in Afghanistan, which he subsequently moved to northeastern Iraq after the United States ousted the Taliban from Afghanistan. Although this camp was located outside territory controlled by the Iraqi government, Baghdad did have an agent in Ansar al-Islam, the radical organization that controlled the area. That agent provided some members of $\mathrm{Al}$ Qaeda safe haven. Powell went on to claim that Al Qaeda associates had moved into the capital, where they operated freely. Further, he asserted that over the past decade there had been frequent contacts between Iraqi agents and Al Qaeda and that interrogation of an $\mathrm{Al}$ Qaeda detainee led to an admission that Iraq provided chemical and biological weapons training for two members of the organization. ${ }^{39}$

US concerns about Iraqi involvement in terrorism were not isolated. Even the Security Council had determined that "Iraq has failed to comply with its commitments pursuant to resolution 687 (1991) with regard to terrorism...." ${ }^{40}$ Assuming that the US allegations were reasonable and made in good faith, did they justify a response in self-defense?

To begin with, by linking Iraq to $\mathrm{Al}$ Qaeda, the issue of anticipatory self-defense becomes moot. Al Qaeda has been conducting a campaign of terrorism against the United States for at least a decade. ${ }^{41}$ Its attacks (planned or executed) can hardly be 


\section{The Legality of Operation Iraqi Freedom under International Law}

characterized as isolated, independent actions, with each response judged separately for compliance with the law of self-defense. US defensive actions are not anticipatory, but rather undertaken in the face of an ongoing campaign.

Was Iraq's involvement in this campaign sufficient to merit an attack directly against the country? It would appear not. The major factor that Powell emphasized was the presence of a key Al Qaeda operative in northern Iraq. However, this was an area beyond the control of the government. Further, to the extent Iraq harbored terrorists, that activity certainly did not rise to the level of Taliban/Al Qaeda connections, with terrorist camps operating openly in Afghanistan. The additional contacts that Powell cited were insufficiently developed to merit characterizing the $\mathrm{Al}$ Qaeda campaign as an armed attack by Iraq. As demonstrated by the international condemnation of the 1998 US cruise missile strike on a Sudanese pharmaceutical plant (in contrast to acceptance of a related strike against a terrorist facility in Afghanistan), the international community insists that the evidence on which States base counter-terrorist defensive operations be reliable. ${ }^{42}$

\section{Anticipatory Self-Defense against WMD and Terrorism}

Although some commentators argued that Iraqi ties to Al Qaeda legally justified Operation Iraqi Freedom as self-defense against an ongoing attack, anticipatory self-defense ${ }^{43}$ found greater support within the legal and policy communities, specifically anticipatory defense against the dual evils of weapons of mass destruction (whether wielded by a State or terrorists) and transnational terrorism (whether State sponsored or not). And Operation Iraqi Freedom made good on President Bush's September 2002 National Security Strategy promise, echoed in his published weapons of mass destruction and terrorism strategies, to act preemptively when necessary. ${ }^{44}$

The inability to deter a potential attacker, the immediacy of today's threats, and the magnitude of potential harm that could be caused by our adversaries' choice of weapons do not permit [relying on a reactive posture]. We cannot let our enemies strike first. ${ }^{45}$

Legal arguments based on anticipatory self-defense usually falter on the criterion of imminency. Recall the international law requirements that an act of self-defense be proportional and necessary to an armed attack that is either imminent or underway. They derive historically from an 1837 incident involving the Caroline, a vessel used to supply Canadian rebels fighting British rule during the Mackenzie Rebellion. British forces crossed into the United States (after asking the United States, 
without result, to put an end to rebel activities on its territory), captured the Caroline, set it ablaze, and sent it over Niagara Falls. Two US citizens perished.

An exchange of diplomatic notes ensued in which Secretary of State Daniel Webster argued that defensive actions require "a necessity of self-defense, instant, overwhelming, leaving no choice of means, and no moment for deliberation ... [and must be] justified by the necessity of self-defence, must be limited by that necessity, and kept clearly within it." 46 Lord Ashburton, his British counterpart, accepted this formula as the basis of their exchange..$^{47}$ Both the International Military Tribunal at Nuremberg and the International Court of Justice have cited the standard with approval. ${ }^{48}$

By any measure of estimation, Iraq was not about to launch an attack on the United States, with weapons of mass destruction or otherwise, in the immediate future. Nor is there any compelling evidence of Iraq distributing weapons of mass destruction to transnational terrorists or in any other way directing or sponsoring specific and imminent attacks on the United States. Rather, the United States believed that Iraq had failed to fully disarm as required by the UN disarmament regime; had not fully accounted for the biological and chemical weapons, such as anthrax and the nerve agent VX it possessed immediately after the first Gulf War; could rapidly produce and disperse more such weapons; was actively concealing efforts to develop additional weapons of mass destruction, as well as existing capabilities, for instance, by dispersing rocket launchers and warheads containing biological warfare agents into western Iraq while Resolution 1441 was under negotiation; was determined to develop a nuclear weapon and was seeking the capability to produce fissile material; and was developing the ability to deliver weapons of mass destruction with ballistic missiles and unmanned aerial vehicles (UAV). ${ }^{49}$ Although assertions that Iraq possessed biological and chemical weapons and a nuclear weapons development program are highly doubtable in light of the failure of post-attack weapons inspectors to discover convincing evidence thereof, ${ }^{50}$ bear in mind that it is the reasonable belief of the attacker, even if mistaken, that is legally relevant.

While these "facts" arguably fail to meet the imminency criterion as it is traditionally understood, in its National Security Strategy the United States has asserted that imminency must be interpreted more liberally in the current circumstances:

We must adapt the concept of imminent threat to the capabilities and objectives of today's adversaries. Rogue states and terrorists do not seek to attack us using conventional means. They know such attacks would fail. Instead, they rely on acts of terror and, potentially, the use of weapons of mass destruction-weapons that can be easily concealed, delivered covertly, and used without warning. ${ }^{51}$ 


\section{The Legality of Operation Iraqi Freedom under International Law}

Indeed, the Congressional joint resolution authorizing the President to commit US forces to battle against Iraq adopted exactly this liberal interpretation of anticipatory self-defense. Whereas Iraq's demonstrated capability and willingness to use weapons of mass destruction, the high risk that the current Iraqi regime will either employ those weapons to launch a surprise attack against the United States or its Armed Forces or provide them to international terrorists who would do so, and the extreme magnitude of harm that would result to the United States and its citizens from such an attack, combine to justify action by the United States to defend itself. . . ${ }^{52}$

Those who urge fidelity to an outdated restrictive interpretation of imminency fail to grasp the realities of twenty-first-century conflict. In an era when the enemy may be a shadowy non-State group intent on remaining invisible until it strikes its blow, a requirement to withhold defensive action until that blow is about to land would render the right to self-defense meaningless. Exacerbating matters is the fact that, given WMD proliferation, any miscalculation as to when an attack will come could be fatal.

If international law is to contribute to the maintenance of global order, the rights and duties it sets out must be interpreted not only in conformity with their core purposes, but also with sensitivity to the security context in which they are applied. The requirement of imminency deters States from resorting precipitously to the most powerful—and potentially destabilizing —option available in international relations. On the other hand, the right of self-defense exists to allow States an effective shield against aggression. In the Charter framework, the recognition of this inherent right compensates for the possibility (a de facto likelihood) that the Chapter VII scheme for maintaining or restoring international peace and security might fail.

A careful balancing of the presumption against using force with the need to allow States an effectual defense suggests the appropriate standard. Stated in the affirmative, a State may act anticipatorily (preemptively) if it must strike immediately to defend itself in a meaningful way and the potential aggressor has irrevocably committed itself to attack. The determinative question when evaluating claims to anticipatory self-defense is whether the defensive action occurred during the last possible window of opportunity in the face of an attack that was almost certainly going to occur.

This approach to imminency generally operates synergistically with the necessity criterion. After all, if the use of force is not the sole remaining viable option for resolving the matter, then in most cases the last window of opportunity will not have been reached.

Assuming, for the sake of analysis, the facts believed by the Coalition at the moment it acted, the case for acting anticipatorily was weak. There is no doubt that 
Iraq presented some threat to the United States and its Coalition partners, particularly given its ties to transnational terrorism, its demonstrated willingness to use weapons of mass destruction, its possession of such weapons, and its decade-long hostility to the United States. However, little evidence existed of an Iraqi intention to use WMD in the near future. Nor did Iraq possess a reliable means of delivering those weapons over great distances. Further, although Iraq unquestionably had connections to terrorism, there was no suggestion that it was about to transfer the weapons it reportedly possessed to terrorists.

On the contrary, both individual States and the United Nations had the country under a microscope. Moreover, the lessons of Afghanistan could not have been lost on the Iraqis. The Iraqi leadership must have realized that any use of WMD against the United States, whether by themselves or Iraqi-supported terrorists, would have proven suicidal. Indeed, use against any State, or even an internal group, would have been exceedingly irrational, for such use would have immediately silenced opposition to a use of force mandate in the Security Council. In fact, UN pressure was serving as an incentive for compliance, a fact apparent in Iraqi acceptance of inspectors pursuant to Resolution 1441, and its subsequent cooperation, however grudging, with them; clearly, the Iraqis feared an attack. To conclude in these circumstances that Iraq was simultaneously planning a strike against the United States or any Coalition partner, and that March 2003 represented the last window of opportunity to mount an effective defense, would have been illogical.

In the case of Iraq, anticipatory self-defense arguably fails on the other two criteria as well. That the Iraqis had not fully complied with the requirements of the relevant Security Council resolutions is unquestionable; but international pressure on Iraq had seen progress, particularly following the US and UK saber rattling and the Council's adoption of Resolution 1441. Neither inspection team believed it had reached a dead end. And the Security Council could not even agree that force was needed to enforce its prior resolutions, an easier conclusion to reach than one that held an attack was forthcoming and only an immediate armed response could stave it off. Thus, Operation Iraqi Freedom falters on the necessity criterion.

But even had an attack been necessary in March 2003, some might have argued that conquest and belligerent occupation of the country was disproportionate. For instance, selected air strikes against WMD-related targets, or perhaps even a rolling campaign designed to impose ever-greater costs, might have compelled Iraq to dismantle its capabilities, cooperate fully with international weapons inspectors, and refrain from further involvement with terrorists. That said, given Saddam Hussein's record of intransigence (and in light of Operation Desert Fox's inability to convince him to readmit weapons inspectors), assertions of disproportionality 


\section{The Legality of Operation Iraqi Freedom under International Law}

are unconvincing. Of course, because the operation was not "necessary" as that term is understood in the law of self-defense, the entire issue is purely theoretical.

\section{Breach of the 1991 Cease-Fire}

The lead Coalition partners, the United States and United Kingdom, did not base the legality of their attack against Iraq on a self-defense argument, anticipatory or otherwise. Before commencing hostilities, the United Kingdom made this clear in a formal opinion of the Attorney General. ${ }^{53}$ The United States issued no comparable official legal opinion, a problem because the US administration was publicly discussing possible reasons for the attack that ranged from WMD and enforcing cease-fires to terrorism and regime change. ${ }^{54}$ However, immediately after launch of Operation Iraqi Freedom, the United States addressed a letter to the President of the Security Council in which it outlined its legal rationale for resorting to armed force, a justification very similar to that contained in the earlier Attorney General opinion. ${ }^{55}$ The United Kingdom did likewise. ${ }^{56}$

It is important to distinguish these formal legal justifications from the myriad other justifications suggested by the US and UK governments, many of which appeared to be robed in the mantle of the law. For instance, in his notification to Congress that the United States was employing force against Iraq, the President stated he has determined that "further diplomatic and other peaceful means alone will neither adequately protect the national security of the United States against the continuing threat posed by Iraq, nor lead to enforcement of all relevant United Nations Security Council resolutions regarding Iraq." ${ }^{57}$ Some might conclude that such statements indicate application of the preemptive self-defense strategy announced in the 2002 National Security Strategy. Such assertions confuse strategy with the underlying legal basis for application of a strategy in particular circumstances. Precision requires distinguishing strategic rationale from underlying legal justification.

To date, the most complete "official" presentation of the legal position taken by the United States is contained in an article coauthored by the US State Department's Legal Adviser, William H. Taft IV, and the Assistant Legal Adviser for Political/Military Affairs, Todd F. Buchwald, in the American Journal of International Law..$^{58}$ In that piece, they amplify on the rationale contained in letters to the Council President. They begin by accurately dispensing with the notion that preemptive self-defense is either necessarily legal or illegal; such assertions are red herrings because the legality of preemptive actions is always fact-specific. ${ }^{59}$ They then turn to the US legal basis for Operation Iraqi Freedom, one grounded in both the situation in 2002-3 and the history of the Iraq case over the past dozen years. Their analysis 
combined with that contained in the US and UK notifications to the Security Council and the Attorney General's opinion yield the following justification for the war.

After Iraq invaded Kuwait on August 2, 1990, the United Nations Security Council passed Resolution 660, declaring the attack a breach of the peace and demanding immediate withdrawal. ${ }^{60}$ Over the ensuing two months, it passed a number of resolutions imposing sanctions on Iraq in the hope of pressuring it to comply with $660 .{ }^{61}$ Finally, on November 29 the Council, pursuant to its Chapter VII authority, adopted Resolution 678, which authorized States cooperating with Kuwait to use "all necessary means" to implement 660 and subsequent resolutions and "to restore international peace and security in the area." ${ }^{2}$ The latter phrase is particularly relevant as it empowered the use of force not merely to expel the Iraqi military from Kuwait, but also to create the conditions necessary for regional stability. In order to afford Iraq "one final opportunity," the resolution set a compliance deadline of January 15, 1991. Meanwhile, the United States and a number of other States had deployed forces to the region "in the exercise of the inherent right of individual and collective self-defense." 63

When Iraq failed to comply with the UN resolutions by the deadline, Coalition forces attacked. This action was taken pursuant to 678, not a new Security Council mandate; thus, individual States—not the Security Council—determined Iraq had not complied and took the decision to attack. By March 3, Iraqi forces were in retreat and field commanders negotiated a cease-fire.

Exactly one month later, the Security Council adopted Resolution 687.64 It set forth the terms of a cease-fire that would come into effect upon Iraqi acceptance, including terms relating to such issues as borders, terrorism, and, most significantly, WMD disarmament. A system of inspections (and weapons destruction) by the United Nations Special Commission (UNSCOM) and IAEA was set up for this latter purpose. Iraq grudgingly accepted the terms on April 6 in a letter to the Security Council. ${ }^{65}$

As a matter of law, material breach of the terms of a cease-fire by one side releases the other from its own obligations, including that to refrain from the use of force. ${ }^{66}$ Those who suggest that breach of a cease-fire contained in a Security Council resolution requires a subsequent use of force mandate before resuming hostilities ignore the fact that the state of war continues during a cease-fire. ${ }^{67}$ Cease-fires are merely temporary cessations of hostilities, usually agreed upon in order to facilitate negotiations on formal termination of hostilities. Only when hostilities have formally ended, for instance through a peace agreement, does the UN Charter Article 2(4) prohibition on the use of force become operative again as between the parties to the conflict. ${ }^{68}$ 


\section{The Legality of Operation Iraqi Freedom under International Law}

On a number of occasions, Coalition forces had responded to Iraqi breaches forcibly, most notably in 1993 and 1998. Although the Security Council did not specifically authorize the use of force either time, significant indications of concurrence with the position that Resolution 678 alone sufficed to justify a resumption of hostilities existed in both cases. Not only did France (an opponent of the 2003 action) participate in the 1993 operation with the United States and United Kingdom, but Secretary-General Boutros-Ghali stated:

the raid was carried out in accordance with a mandate from the Security Council under resolution 678 (1991), and the motive for the raid was Iraq's violation of that resolution which concerns the cease-fire. As General-Secretary of the United Nations, I can tell you that the action was taken in accordance with the resolutions of the Security Council and the Charter of the United Nations. ${ }^{69}$

Similarly, following the 1998 Operation Desert Fox strikes, a vituperative debate over the necessity of a Security Council Resolution finding Iraq in material breach as a condition precedent to attack took place; tellingly, this debate assumed that if the Security Council had rendered such a finding, States could have used force in response thereto. ${ }^{70}$

In fact, in the years following implementation of the cease-fire, the Security Council found Iraq in non-compliance with Security Council resolutions on multiple occasions. For instance, in August 1991, the Council condemned Iraq's "serious violation of a number of its obligations under ... resolution 687 (1991) and of its undertakings to cooperate with the Special Commission and the International Atomic Energy Agency, which constitutes a material breach of the relevant provisions of that resolution which established a cease-fire. ..."71 In March 1998, the Council issued a stern warning to Iraq that "compliance ... with its obligations ... to accord immediate, unconditional and unrestricted access to the Special Commission and the IAEA, in conformity with the relevant resolutions, is necessary for the implementation of resolution 687 (1991) ... [and] that any violation would have the severest consequences for Iraq." 72 That November, the Council condemned Iraq for "the decision ... of 31 October 1998 to cease cooperation with the Special Commission" and labeled the step a "flagrant violation of resolution 687 (1991) and other relevant resolutions...."73 Operation Desert Fox commenced on December 16, 1998 and continued for three days, but Iraq refused to admit inspectors for the next four years.

The most relevant finding of breach came when the Security Council unanimously adopted Resolution 1441 on November 8, 2002. As outlined above, in that resolution the Council determined that Iraq had failed to comply with 
requirements to disclose WMD information, cooperate with weapons inspectors, cut ties to terrorists, cease repression of its population, facilitate humanitarian assistance, and cooperate in accounting for human and property losses from the first Gulf War. It affirmed "Iraq has been and remains in material breach of its obligations under relevant resolutions, including resolution 687 (1991), in particular through Iraq's failure to cooperate with United Nations inspectors and the IAEA and to complete actions required under paragraphs 8-13 of resolution 687 (1991)." 74 Resolution 1441 also specifically "recalled" that Resolution 678 had authorized the use of "all necessary means" to uphold and implement both prior and subsequent relevant UN resolutions (thereby including 1441) and restore international peace and security. The Council afforded Iraq a "final opportunity" to meet its obligations, but "failure by Iraq at any time to comply with and cooperate fully in the implementation of this resolution [which requires a declaration on all aspects of the Iraqi WMD program and cooperation with inspectors] shall constitute a further material breach of Iraq's obligation. . ." (emphasis added). Resolution 1441 concluded with a stern warning of "serious consequences" in the event of "continued violation [by Iraq] of its obligations." Significantly, 1441 required the Security Council to reconvene if Iraq did not fulfill its obligations. As noted earlier, the Council did so to consider the reports of weapons inspectors, who did not give Iraq a clean bill of health, and the concerns of individual States, most notably the United States.

What Resolution 1441 did not contain was a requirement to return to the Council for a use of force authorization. As noted by the US legal advisers, earlier drafts circulated among the Security Council members required the Council to meet again to "decide any measures to ensure full compliance of all its relevant resolutions." 75 Negotiations led to the rejection of this wording.

Based on these facts, the United States and its coalition partners presented a rather linear argument. Resolution 687 (1991) conditioned the cease-fire on Iraqi compliance with its terms. Iraq had not fully complied, resulting in several Security Council declarations that such non-compliance amounted to material breach. The Council even gave Iraq a "final opportunity" to bring itself into conformity and placed Iraq on notice that further non-compliance would constitute a material breach which could result in serious consequences. In the US view, the Security Council should have acted at that point to enforce its own resolutions, but did not. Therefore, the United States and other Coalition States were released from their cease-fire obligations and the initial use of force authorization contained in Resolution 678 became operative again, as it had on multiple occasions in the previous decade. The sole limitation on their actions was that they do no more than authorized by the broad mandate contained in Resolution 678 — to enforce past and 


\section{The Legality of Operation Iraqi Freedom under International Law}

future Council resolutions and restore international peace and security. Given more than a decade of violation of Security Council resolutions intended to create the conditions for stability, ousting Saddam Hussein and the Baathists from power fell neatly within that mandate.

As a matter of law, this line of argumentation is sound. Under the principles of humanitarian law, cease-fires are clearly temporary measures that bind parties thereto only so long as the other side is not in material breach. The Security Council had agreed in November 2002 that Iraq was in breach (thereby mooting any argument about whether a US or UK assertion of breach was justified). Further, immediately prior to the attack the UN's own inspectors asserted that the Iraqis were not meeting all the requirements imposed on them, a situation which 1441 had pre-determined to be a further material breach. As a general matter of law, hostilities may immediately resume in the event of material breach. In this particular case, the right to resume hostilities was clearer still, for the cease-fire resolution specifically reaffirmed Resolution 678, which authorized the use of force, "except as expressly changed." The only change to that resolution was imposition of the cease-fire itself. But with the cease-fire materially breached, the 678 use of force authorization came back into play by the express terms of Resolution 687 .

Some have claimed that only the Security Council was authorized to determine how to respond to the cease-fire breach it had acknowledged in Resolution 1441 and previous resolutions. However, such assertions ignore the fact that the ceasefire was not between the United Nations and Iraq, but, according to 687, "Iraq and Kuwait and member States cooperating with Kuwait in accordance with resolution 678 (1990)." Therefore, those States were empowered under international law to determine whether to resort to force once a material breach of the cease-fire to which they were a Party occurred. ${ }^{76}$ The fact that Resolution 687 provided the Security Council remained "actively seized of the matter" has similarly been misinterpreted as indicating that exclusive authority to mandate a response resided in the Council. In fact, the phrase is nothing more than standard text appearing in many resolutions indicating the Security Council will continue to address the situation at hand (as it did with 1441 and other post-687 resolutions). Unless specifically provided, such text does not preclude actions (that are in compliance with international law) taken by States or other international governmental organizations to respond to a situation. It has also been argued that the use of force authorization was limited to expelling the Iraqis from Kuwait, and that any use of force beyond that purpose would require further Council authorization. However, the stated purpose of 678 was to "uphold and implement resolution 660 (1990) and all subsequent resolutions and to restore international peace and security in the area." That this was a broad grant of authority is evidenced by inclusion of the diversity of 
cease-fire terms (from borders to disarmament) in Resolution 687. Clearly, in 1990-91, the Council understood that restoring international peace and security involved much more than merely liberating Kuwait.

Admittedly, this line of analysis, albeit legally valid, poses a difficult practical dilemma, for the views of the Security Council on the use of force against Iraq differed dramatically in March 2003 from those of April 1991. Yet, the Council, in the face of US and UK opposition, was powerless to withdraw, or even modify, either its 1990 use of force authorization or the terms of its 1991 cease-fire. ${ }^{77}$ This is a particularly vexing problem given post-conflict difficulties of finding the WMD or terrorism smoking guns. Thus, we witnessed a use of force based on Security Council resolutions that the Council itself would not have approved had it been the sole decision-maker. It represented the triumph of law over policy.

In the future, the Council is likely to be very reticent about granting open-ended continuing authority to employ force. In particular, it can be expected to carefully craft its Chapter VII resolutions to require explicit follow-on authorization for any resumption of hostilities should a cessation of hostilities occur. That said, the paradoxical legal fact remains that based on the interplay of a series of Security Council resolutions and the law of cease-fires, Operation Iraqi Freedom was legal.

\section{Humanitarian Intervention}

There is no question that the Security Council could have authorized an intervention into Iraq based on the regime's mistreatment of its population. In doing so, the internal situation need merely have represented a "threat to the peace" under Article 39 of the Charter, such that the Council's Article 42 authority vested. Since the Council itself determines when a threat has emerged, it enjoys unfettered discretion in authorizing a forcible humanitarian intervention under Chapter VII of the Charter.

The Security Council has mandated such interventions on numerous occasions. For instance, when internal order in Somalia collapsed in 1992, the Council authorized "member States ... to use all necessary means to establish as soon as possible a secure environment for humanitarian relief operations in Somalia."78 The United States responded with Operation Restore Hope, conducted by the multinational Unified Task Force (UNITAF). The following year, acting under Chapter VII, the Council approved the replacement of UNITAF by the United Nations Operation in Somalia (UNOSOM) II. ${ }^{79}$

The nature of the intervention need not be classically humanitarian. In 1994, the Security Council authorized member States to forcibly intervene in Haiti to effect the "restoration of the legitimate authorities of the Government of Haiti." 80 


\section{The Legality of Operation Iraqi Freedom under International Law}

Although the resolution cited the humanitarian situation in the country, including the denial of civil liberties, the intent was clearly political in purpose-regime change through "the prompt return of the legitimately elected President, JeanBertrand Aristide, within the framework of the Governors Island Agreement." 81

Some humanitarian interventions mounted without Security Council sanction have subsequently acquired the support of the Council. In 1990, the Economic Community of West African States (ECOWAS) intervened in Liberia without UN approval. The following year, a Security Council Presidential Statement "commended the efforts made by the ECOWAS Heads of State and Government to promote peace and normalcy in Liberia." 82 When fighting broke out again in 1992, the Council praised ECOWAS for its role in addressing this "threat to international peace and security." 83 ECOWAS conducted yet another humanitarian intervention without Security Council sanction in 1997 when events in Sierra Leone slipped out of control. As in the Liberia case, an ex post facto Presidential Statement commended ECOWAS for the "important role" it was playing "towards the peaceful resolution of this crisis." 84

Although also conducted without Security Council objection, these cases can be readily distinguished from the situation in Iraq. First, regional organizations carried them out, thereby adding some degree of legitimacy to the operations. Further, there was no apparent opposition to the interventions in the Security Council, and certainly none from any of the Permanent Five. Finally, in both countries the humanitarian crisis was widespread, immediate, and horrendous.

The 1999 NATO intervention in Kosovo represents a closer case because there the Security Council had previously labeled the situation a threat to the peace as in Iraq and the operation was mounted in the face of opposition on the Security Council, most significantly from Russia. Unsurprisingly, Operation Allied Force generated significant criticism from the international legal community. Although few contested the legitimacy of the NATO operation, many supporters acknowledged the frailty of its asserted legal basis. Kosovo was not, after all, Rwanda, where deaths numbered in the hundreds of thousands. In that case, individual States and the international community were roundly criticized for inaction; but it was the scale of the tragedy that tended to underpin such criticism. ${ }^{85}$

Even with the rise of concepts such as human rights, human dignity, world order, and sovereignty residing in the citizenry rather than the government, international law continues to react negatively to the prospect of State A determining that events in State B merit resort to the use of force. UN Charter Article 2(4), which prohibits the use of force against the territorial integrity or political independence of any State, continues to enjoy normative positive valence. Asserting exceptions to this prohibition beyond those found within the four corners of the Charter- 
self-defense and Security Council authorization—inevitably generates skepticism and opposition.

Iraq lies further down the continuum of situations that might legally justify humanitarian intervention than the aforementioned cases. With Iraq, no regional organization rose to the challenge of intervention. On the contrary, close allies of those who did attack Iraq were openly opposed to intervention without Council approval. Further, the humanitarian situation in the country, albeit deplorable, did not rise to the level of suffering of the previous precedents. In the period preceding the attack, there is no question that torture was widespread, ethnic minorities were expelled from their homes, infant and child mortality rates had grown dramatically as a result of Saddam Hussein's non-cooperation with the "food-for-oil" program assets, and that the humanitarian situation was generally deteriorating. ${ }^{86}$ Nevertheless, the scale and scope of suffering had not reached genocidal proportions as it had in Rwanda, nor was there fear of an imminent campaign of genocide, as in Kosovo. Simply put, the human situation in the country was not at a point where a majority of international legal scholars and practitioners would agree that a factual basis for humanitarian intervention, a controversial matter in international law even in the abstract, existed.

Thus, while the regime's treatment of the Iraqi population was morally and legally reprehensible, and although President Bush repeatedly cited such treatment as a rationale for action against Iraq (for example, during his 2002 State of the Union Address), it did not justify humanitarian intervention absent Security Council de jure or de facto acquiescence. Although the jus ad bellum has moved in the direction of increased acceptance of humanitarian intervention since the end of the Cold War, by March 2003 it had not reached situations such as that in Iraq. Thus, it is unsurprising that none of the countries participating in Operation Iraqi Freedom formally cited the internal suffering as legally justifying their action.

\section{Regime Change}

In 1998, a distinguished group of individuals, many of whom now occupy key positions in the Bush administration, openly urged the removal by force of Saddam Hussein's regime. ${ }^{87}$ Clearly, the Administration desperately desired regime change in Iraq. Yet, despite a self-evident need for a new regime in the country, and although the US administration actually demanded on March 17, 2003 that Saddam Hussein step down within 48 hours or face forceful removal, ${ }^{88}$ there is no independent basis in international law for regime change. Rather, regime change can only be a legitimate consequence of otherwise legal uses of force. ${ }^{89}$ 


\section{The Legality of Operation Iraqi Freedom under International Law}

For example, the Security Council may determine that continued governance by a particular group threatens international peace and authorize the removal of that government under Chapter VII, as it did in the case of Haiti in 1994. Or it may determine that another situation amounts to a threat to the peace, breach of peace, or act of aggression and authorize the use of military force pursuant to Article 42 to restore international peace and security. If the fall of a regime results from the ensuing military action, that regime change would be legal. For instance, many argue that Coalition forces should have marched on Baghdad in 1991 to topple Saddam Hussein because with the dictator still in power it was impossible to permanently restore international peace and security pursuant to Resolution 678. Similarly, an effective defense, either individual or collective, may result in the fall of the regime that mounted an aggressive attack. It is even possible that a humanitarian intervention could result in removal of a regime, either as a coincidental consequence of the operation or because doing so is necessary to safeguard the civilian population. That certainly would have been the case with the Hutu-dominated government of Rwanda had external forces intervened in 1994 to stop its slaughter of the Tutsis. However, States may not, absent Security Council mandate, act for the sole purpose of removing a regime of which they disapprove; doing so would constitute a patent violation of Article 2(4) of the UN Charter. Therefore, in the absence of a separate legal basis for action (which existed in this case), any effort to remove Saddam Hussein from power would have been illegal.

\section{Conclusions}

Despite the often-confusing rhetoric that has accompanied Operation Iraqi Freedom, there is only one legal basis on which the action could have been plainly justified, and it is on that basis that the States forming the coalition against Saddam Hussein rested their case. Therefore, the war against Iraq is unlikely to impact current understanding of the jus ad bellum in any dramatic way, as Operation Enduring Freedom did with regard to the use of force against terrorists and their State supporters.

If anything (and somewhat counter-intuitively), the affair is likely to strengthen the centrality of the UN Charter use of force regime and the Security Council's role in determining when States may employ armed force. All parties agreed that first resort in the matter was to the Security Council. Indeed, the United States and its Coalition allies actively sought a use of force mandate from the Council. When they did not receive one, they nevertheless justified their actions on a string of Security Council resolutions reaching back over a decade. Analogously, States opposed to Operation Iraqi Freedom based their resistance on 
the argument that the Coalition should not have attacked without an explicit Council mandate.

Had the Coalition chosen any other ground to justify the attack, currently prevailing interpretations of the jus ad bellum would have been placed under significant stress, with some scholars and practitioners arguing for new interpretations of existing law in light of changed circumstances, others suggesting the emergence of new norms, and many asserting that the attack was quite simply unlawful. It is fortunate that the Coalition avoided alternative justifications, for, as every law student knows, hard cases make bad law. Instead, the lesson of this experience is that States will continue to look to the Security Council as the font for authorization to use force; therefore, that body must exercise its discretion with great care, surgical precision, and an eye to the future.

\section{Notes}

1. At the time of the attack, 49 nations were publicly committed to the Coalition. Support ranged from contributions of troops to political actions. White House Press Release, Operation Iraqi Freedom: Coalition Members, Mar. 27, 2003, available at http://www.whitehouse.gov/ news/releases/2003/03/20030327-10.html.

2. Patrick E. Tyler \& Felicity Barringer, Annan Says U.S. Will Violate Charter If It Acts Without Approval, NeW YORK TIMES, Mar. 11, 2003, at A10. Many academics also found the war illegal. See, e.g., the letter from 16 law professors, THE GUARDIAN (London), Mar. 7, 2003, at 29. But see also Adam Roberts, Law and the Use of Force After Iraq, SURVIVAL, Summer 2003, at 31 (2003). For an excellent compilation of articles on both sides of the issue, see Future Implications of the Iraq Conflict, SELECTIONS FROM THE AMERICAN JOURNAL OF INTERNATIONAL LAW (2004).

3. That component of international law that governs when a State may resort to force in pursuit of its national interests, such as defending itself from armed attack or acting pursuant to a mandate from the United Nations Security Council. It is distinguished from the jus in bello, which addresses the conduct of actual hostilities, for example by providing certain objects and individuals protected status during hostilities.

4. The 1999 NATO war against the Federal Republic of Yugoslavia and the 2001 war against Afghanistan, respectively.

5. U.N. CHARTER art. 41.

6. SC Res. 678 (Nov. 29, 1990).

7. SC Res. 660 (Aug. 2, 1990).

8. The Council used ad hoc coalitions for operations against Iraq in 1990-1 (SC Res. 678, supra note 6) and to set up the initial International Security Assistance Force in Afghanistan in 2001 (SC Res. 1368 (Sept. 12, 2001)). By contrast, the Council turned to NATO to lead KFOR in Kosovo in 1999 (SC Res. 1244 (June 10, 1999)). An example of a "blue helmeted" force is UNAMSIL in Sierra Leone, which received its first mandate in 1999 (SC Res. 1270 (Oct. 22, 1999)).

9. SC Res. 1441 (Nov. 8, 2002).

10. Required by SC Res. 687 (Apr. 3, 1991).

11. Specifically, the United Nations Special Commission (UNSCOM), International Atomic Energy Agency (IAEA), and United Nations Monitoring, Verification and Inspection 


\section{The Legality of Operation Iraqi Freedom under International Law}

Commission (UNMOVIC). Although Resolution 687 required cooperation with the first two, Iraq expelled both in 1998. UNMOVIC was established as the successor to UNSCOM (SC Res. 1284 (Dec. 17, 1999)).

12. Required by SC Res. 687, supra note 10 .

13. Required by SC Res. 688 (Apr. 5, 1991).

14. Required by id.

15. Required by SC Res. 686 (Mar. 2, 1991); 687, supra note 10; 1284, supra note 11.

16. Text of 4714th meeting, SC, U.N. Doc. S/PV.4714 (Mar. 7, 2003).

17. SC Res. 687, supra note 10.

18. Text of 4644th mtg., SC, U.N. Doc. S/PV.4644 (Nov. 8, 2002).

19. Id.

20. Id.

21. Briefing by Secretary of State Powell to the Security Council, U.N. Doc. S/PV.4701 (Feb. 5, 2003).

22. White House Press Release, President Says Saddam Hussein Must Leave Iraq within 48 Hours. Remarks by the President in Address to the Nation, Mar. 17, 2003, available at http:// www.whitehouse.gov/news/releases/2003/03/20030317-7.html.

23. "All Members shall refrain in their international relations from the threat or use of force against the territorial integrity or political independence of any state, or in any other manner inconsistent with the Purposes of the United Nations." U.N. CHARTER art. 2, para 4.

24. E.g., SC Res. 1378 (Nov. 14, 1991); SC Res. 1386 (Dec. 20, 2001); SC Res. 1390 (Jan. 20, 2002).

25. See, e.g., W. Michael Reisman, International Legal Responses to Terrorism, 22 HOUSTON Journal OF INTERNATIONAL LAW 3, 33-4 (1999); Stuart G. Baker, Comparing the 1993 U.S. Airstrike on Iraq to the 1986 Bombing of Libya: The New Interpretation of Article 51, 24 GEORGIA JOURNAL OF INTERNATIONAL AND COMPARATIVE LAW 99 (1994).

26. GA Res. 41/38 (Nov. 20, 1986).

27. Israelis Praise It While Arabs Vow to Avenge It, ChiCAgo TribUne, Apr. 16, 1986, at A9.

28. Military and Paramilitary Activities (Nicar. v. U.S.), 1986 I.C.J. 14 (June 27).

29. Id. at 103, para. 195 .

30. Id.

31. Letter from the Permanent Representative of the United States of America to the United Nations Addressed to the President of the Security Council, U.N. Doc. S/2001/946 (Oct. 7, 2001).

32. Sean D. Murphy, Contemporary Practice of the United States Relating to International Law, 96 AMERICAN JOURNAL OF INTERNATIONAL LAW 237 (2002); Sean D. Murphy, Terrorism and the Concept of "Armed Attack" in Article 51 of the U.N. Charter, 43 HARVARD INTERNATIONAL LAW JOURNAL 41 (2002).

33. Murphy, Contemporary Practice, supra note 32, at 248. The European Council "confirm[ed] its staunchest support for the military operations ... which are legitimate under the terms of the United Nations Charter and of Resolution 1368." Declaration by the Heads of State or Government of the European Union and the President of the Commission: Follow-up to the September 11 Attacks and the Fight Against Terrorism, Oct. 19, 2002, SN 4296/2/01 Rev. 2.

34. See, e.g., SC Res. 1267 (Oct. 15, 1999); SC Res. 1363 (July 30, 2001); SC Res. 1378, supra note 24; SC Res. 1390, supra note 24.

35. President George W. Bush, Address Before a Joint Session of Congress on the United States Response to the Terrorist Attacks of September 11, 37 WEEKLY COMPILATION OF PRESIDENTIAL 
Michael N. Schmitt

DoCUMENTS 1347 (Sept. 20, 2001). The United States also made back-channel demands through Pakistan.

36. This principle was articulated most notably in the Rendulic case. German General Rendulic was accused of excessive destruction during the German evacuation of Norway. He was acquitted of the charge on the basis of his (mistaken) belief that his forces were being pursued by the Russians and that therefore the destruction was necessary to deny them resources. The Hostages Case (U.S. v. List et al.), 11 T.W.C. 759, 1253-54 (1950). Note that the International Criminal Court Statute provides that mistake of fact is a ground for excluding criminal responsibility if it negates the mental intent element of the offense. Rome Statute of the International Criminal Court art. 32, July 17, 1998, 2187 U.N.T.S. 90.

37. Proportionality and necessity have specifically been cited as customary international law by the International Court of Justice. Military and Paramilitary Activities, supra note 28, at 103, para. 194; Oil Platforms (Iran v. U.S.), Merits (Nov. 6, 2003), 42 INTERNATIONAL LEGAL MATERIALS 1334, 1353, 1361, paras. 43 \& 74, available at http://www.icj-cij.org/icjwww/idocket/ iop/iopframe.htm.

38. U.N. Doc. S/PV.4701 (Feb. 5, 2003).

39. Id. at 14-7.

40. SC Res. 1441, supra note 9.

41. For a fuller discussion of this analysis, see Michael N. Schmitt, Counter-terrorism and the Use of Force in International Law, 32 ISRAEL YEARBOOK ON HUMAN RIGHTS 53 (2002). Prior to the attacks of September 11,2001, the various attacks were primarily characterized as criminal in nature. 9/11, as explained in the cited article, fundamentally altered the international community's perspective on transnational terrorism as a matter of law.

42. See id. for a fuller discussion of this point.

43. For a comprehensive analysis of the law underpinning anticipatory self-defense, see George Walker, Anticipatory Collective Self-Defense in the Charter Era: What the Treaties Have Said, in THE LAW OF MilitARY OPERATIONS 365 (Michael N. Schmitt ed., 1998) (Vol. 72, US Naval War College International Law Studies).

44. The White House, National Security Strategy of the United States of America (2002); The White House, National Strategy to Combat Weapons Of Mass Destruction (2002); THE White House, NATIONAL STRATEGy FOR COMBATING TERrorisM (2003).

45. The Secretary of Defense's Annual Report makes the same point in a "lessons learned" section: " $[D]$ efending the United States requires prevention and sometimes preemption. It is not possible to defend against every threat, in every place, at every conceivable time. The only defense . . . is to take the war to the enemy. The best defense is a good offense." Donald $\mathrm{H}$. Rumsfeld, Annual Report to the President and the Congress 30 (2002), available at www.defenselink.mil/execsec/adr2002/pdf_files/chap3.pdf.

46. Letter From Daniel Webster, US Secretary of State, to Henry Fox, British Minister in Washington (Apr. 24, 1841), in 29 BRITISH AND FOREIGN STATE PAPERS 1840-1841, at 1138 (1857).

47. Letter from Lord Ashburton to Daniel Webster, US Secretary Of State (July 28, 1842), in 30 BRITISH AND FOREIGN STATE PAPERS 1841-1842, at 1858 (1857), available at http:// www.yale.edu/lawweb/avalon/diplomacy/britain/br-1842d.htm.

48. International Military Tribunal (Nuremberg), Judgment And Sentences, 41 AMERICAN JOURNAL OF INTERNATIONAL LAW 172, 205 (1947); Military and Paramilitary Activities, supra note 28, at 94, para. 176; Legality of the Threat or Use of Nuclear Weapons, Advisory Opinion, 1996 I.C.J. 226, 245, para. 41 (8 July); Oil Platforms, supra note 37, at 1353, 1361, paras. 43 and 


\section{The Legality of Operation Iraqi Freedom under International Law}

74. See also RESTATEMENT (THIRD) OF THE FOREIGN RELATIONS LAW OF THE UNITED STATES 905 (1987).

49. Powell Briefing, supra note 21.

50. For instance, former Director of the Iraq Survey Group, David Kay, admitted that "we were almost all wrong" with regard to the Iraqi weapons of mass destruction programs when testifying before the Senate Armed Services Committee in January 2004. That said, he opined that Iraq clearly violated Resolution 1441. Transcript: David Kay at Senate Hearing, Jan. 28, 2004, http://www.cnn.com/2004/US/01/28/kay.transcript/.

51. NATIONAL SECURITY STRATEGY, supra note 44, at 15.

52. Authorization for the Use of Military Force Against Iraq Resolution of 2002, Public Law No. 107-243, 116 Stat. 1498, 1499 (2002).

53. Lord Goldsmith, Attorney General Clarifies Legal Basis for the Use of Force Against Iraq (Mar. 18, 2003), http://www.fco.gov.uk/servlet/Front?pagename=OpenMarket/Xcelerate/ ShowPage\&c=Page\&cid $=1007029393879 \& a=$ KArticle\&aid $=1047661460790$.

54. In the days immediately preceding the attack, President Bush did indicate, however, that the primary basis for the forthcoming operation was to be found in Security Council Resolutions 678, 687, and 1441. White House Press Release, supra note 22. This speech was made on March 17, the same day the UK Attorney-General appeared before the House of Lords and offered essentially the same position. It would appear that by this point, the United States and United Kingdom had reached agreement on the justification, among the many that had been circulating unofficially, for their forthcoming action.

55. Letter dated March 20, 2003 from the Permanent Representative of the United States of America to the United Nations addressed to the President of the Security Council, U.N. Doc. S/ 2003/351 (Mar. 21, 2003), available at http://documents-dds-ny.un.org/doc/UNDOC/GEN/ N03/290/79/doc/N0329079.DOC?OpenElement.

56. Letter dated March 20, 2003 from the Permanent Representative of the United Kingdom of Great Britain and Northern Ireland to the United Nations addressed to the President of the Security Council, U.N. Doc. S/2003/350 (Mar. 21, 2003), available at http://documents-ddsny.un.org/doc/UNDOC/GEN/N03/290/73/pdf/N0329073.pdf?OpenElement.

57. Text of a Letter from the President to the Speaker of the House of Representatives and President Pro Tempore of the Senate, Mar. 21, 2003, available at http://www.whitehouse.gov/ news/releases/2003/03/20030321-5.html.

58. William H. Taft \& Todd F. Buchwald, Preemption, Iraq, and International Law, 97 AMERICAN JOURNAL OF INTERNATIONAL LAW 557 (2003).

59. On the topic of preemption in international law, see Michael N. Schmitt, Preemptive Strategies in International Law, 97 MICHIGAN JOURNAL OF INTERNATIONAL LAW 513 (2003).

60. SC Res. 660, supra note 7.

61. SC Res. 661 (Aug. 6, 1990); 662 (Aug. 9, 1990); 664 (Aug. 18, 1990); 665 (Aug. 25, 1990); 667

(Sept. 16, 1990); 670 (Sept. 25, 1990); 674 (Oct. 29, 1990); 677 (Nov. 28, 1990).

62. SC Res. 678 , supra note 6.

63. Letter dated 9 August 1990 from the Permanent Representative of the United States of America to the United Nations, U.N. Doc. S/21492 (Aug. 10, 1990).

64. SC Res. 687, supra note 10.

65. Letter from Permanent Representative of Iraq to Secretary-General and Security Council President, U.N. Doc. S/22456 (Apr. 6, 1991), reprinted in JOHN N. MOORE, CRISIS IN THE GULF 497 (2002). 
66. This is a matter of customary international law, codified in the context of armistices, in Articles 36 and 40 of the 1907 Hague Regulations Respecting the Laws and Customs of War on Land, Oct. 18, 1907, 36 Stat. 2277, 1 Bevans 631.

67. See, e.g., Jules Lobel \& Michael Ratner, Bypassing the Security Council: Ambiguous Authorizations to Use Force, Cease-fires and the Iraqi Inspection Regime, 93 AMERICAN JOURNAL OF INTERNATIONAL LAW 124 (1999).

68. On this point, see Yoram Dinstein, War, Aggression, and Self-Defence (3d ed., 2001).

69. Transcript of Press Conference by Secretary-General Boutros Boutros-Ghali Following Diplomatic Press Club Luncheon, Paris, Jan. 14, 1993, U.N. Doc. SG/SM/4902/Rev. 1, at 1.

70. Taft \& Buchwald, supra note 58, at 560. The United States specifically grounded its operation on previous resolutions. As President Clinton noted, the armed action was "consistent with and has been taken in support of numerous U.N. Security Council resolutions, including Resolutions 678 and 687. . . ." Letter to Congressional Leaders on the Military Strikes against Iraq, reprinted in 2 PUBLIC PAPERS 2195 (Dec. 18, 1998).

71. SC Res. 707 (Aug. 15, 1991).

72. SC Res. 1154 (Mar. 2, 1998).

73. SC Res. 1205 (Nov. 5, 1998). Other significant examples of the Security Council finding Iraq in non-compliance include SC Res. 1060 (June 12, 1996); SC Res. 1115 (June 21, 1997); SC Res. 1137 (Nov. 12, 1997).

74. Paragraphs 8-13 provide for the destruction under international supervision of weapons and missiles, reports on possession of particular items, cooperation with UNSCOM and the IAEA, and a commitment to refrain from further development or acquisition of prohibited items.

75. Taft \& Buchwald, supra note 58 , at 562 .

76. There is some controversy over the impact of the Vienna Convention on the Law of Treaties (considered a restatement of customary law for non-Parties) on the cease-fire breach. Vienna Convention, May 23, 1969, 1155 U.N.T.S. 331 (entered into force January 27, 1980). Article 60(2) provides that in the event of a material breach by one of the parties to a multilateral treaty, the others can suspend the treaty's operation in whole or in part by unanimous agreement. However, it also provides that if a party is "specially affected" by the breach, that party can unilaterally suspend as between itself and the breaching party. Thus some have suggested the former principle means that the United States and the United Kingdom could not alone determine the cease-fire to be suspended, whereas others argue they are specially affected and, therefore, could do exactly that. A better approach is to view the matter less legalistically and focus instead on the lex specialis of the humanitarian law of cease-fires. This would allow any party to the cease-fire to resume hostilities in the event of a material breach.

77. The practice of the Security Council in terminating a use of force authorization is to either expressly terminate in a subsequent resolution or provide an expiration date in the authorization itself. An example of the former is Resolution 1031 (SC Res. 1031 (Dec. 15, 1995) (Bosnia), whereas examples of the latter include Resolutions 954 (SC Res. 954 (Nov. 4, 1994)) (Somalia) and 929 (SC Res. 929 (June 22, 1994)) (Rwanda).

78. SC Res. 794 (Dec. 3, 1992).

79. SC Res. 814 (Mar. 26, 1993).

80. SC Res. 940 (July 31, 1994).

81. Id.

82. U.N. Doc. S/22133 (Jan. 22, 1991).

83. SC Res. 788 (Nov. 19, 1992).

84. U.N. Doc. SC/6481 (Feb. 26, 1998). 


\section{The Legality of Operation Iraqi Freedom under International Law}

85. See Report of the Independent Inquiry into the Actions of the United Nations During the 1994 Genocide in Rwanda, annexed to Letter dated 15 December 1999 from the SecretaryGeneral addressed to the President of the Security Council, U.N. Doc. SC/1999/1257 (Dec. 16, 1999), available at http://daccessdds.un.org/doc/UNDOC/GEN/N99/395/47/IMG/ N9939547.pdf?OpenElement.

86. Human Rights WATCH, Forcible EXPUlsion of ETHNiC MinORities (March 2003); Human Rights Watch, IRAQ: The DEATH PENALTy, EXECUTIONS, AND "PrisOn Cleansing" (2003); HUMAN RightS WATCH, THE IRAQI GOVERNMENT ASSAULT ON THE MARSH ARABS (2003); AMNESTY INTERNATIONAL, ANNUAL COUNTRY REPORTS (1995-2003), available at www.amnestyusa.org/countries/iraq/index.do; Reports of the Special Rapporteur of the UN Commission on Human Rights on the Situation of Human Rights in Iraq, available at http:// ap.ohchr.org/documents/dpage_e.aspx? $\mathrm{m}=88$.

87. Letter to the President (William Clinton), Jan. 26, 1998, www.newamericancentury.org/ iraqclintonletter.htm. The group included Richard Armitage, John Bolton, Peter Rodman, Donald Rumsfeld, and Paul Wolfowitz.

88. White House Press Release, supra note 22.

89. The Iraq Liberation Act expressed the "sense of Congress" that it should be the policy of the United States to support efforts to remove the regime headed by Saddam Hussein from power in Iraq and to promote the emergence of a democratic government to replace that regime. The act authorized support to the Iraqi opposition, but did not purport to authorize any use of force by the United States. Public Law No. 105-338, 112 Stat. 3178 (1998). 